\title{
GRANITÓIDES SANTA LUZIA: REGISTRO DO MAGMATISMO GRANÍTICO BRASILIANO DO CINTURÃO ARAGUAIA NA REGIÃO DE PARAIISO DO TOCANTINS (TO)
}

\author{
CLÁUDIO NERY LAMARÃO * \& BASILE KOTSCHOUBEY **
}

\begin{abstract}
SANTA LUZIA GRANITOIDS: RECORD OF BRASILIANO GRANITIC MAGMATISM OF THE ARAGUAIA BELT IN THE PARAÍSO DO TOCANTINS REGION (TO) The Brasiliano granitic magmatism of the Araguaia Belt is expressed, from Xambioá region southwards, by a few isolated stocks (Ramal do Lontra granite, Presidente Kennedy granodiorite) that have been emplaced along the eastern margin of this megastructure. However, in the Paraíso do Tocantins region, the Brasiliano granite bodies appear to be much more abundant and constitute the informally denominated Santa Luzia Granitoids. They occur mainly as small stocks, dykes, veins and lenses intruded into the biotite schist and quartzites of the Estrondo Group (Upper Proterozoic), concordantly or not with the foliation of these metasediments. Such spatial relationship with the host rocks suggests that these granitoids are syn to late-tectonic. Petrographic and geochemical studies revealed that these rocks are peraluminous and consist essentially of granodiorites, monzogranites and pegmatoid granites which possibly resulted from differentiation of a single original magma. $\mathrm{K} / \mathrm{Rb}$ and $\mathrm{Rb} / \mathrm{Sr}$ ratios are fairly constant and indicate that Santa Luzia granitoids were originated from weakly fractionated magmas generated within the continental crust. The $\mathrm{Ca}$ and $\mathrm{Sr}$ contents as well as the $" \mathrm{Sr} /{ }^{\wedge} \mathrm{Sr}$ ratios $=0.707$ support this hypothesis and point out the gneissic basement (Colmeia Complex) as the principal source of these magmas. The presence of angular enclaves of schist in the granitoids and the sharp borders of these xenoliths suggest that the supracrustal metasediments contributed only subordinately to the formation of these magmas. Finally, these rocks show a trend similar to that of low Ca granites and plot within the field of the island arc granitoids, but close to the field of syn-collisional granitoids on a $\mathrm{Rb}-(\mathrm{Y}+\mathrm{Nb})$ diagram. It is concluded that the Santa Luzia granitoids are syn-collisional.
\end{abstract}

Keywords: Brasiliano, Araguaia Belt, granitoids, Peraluminous.

RESUMO O magmatismo granítico Brasiliano do Cinturão Araguaia é representado, a partir da região de Xambioá em direcão ao sul, por pequenos stocks isolados (Granito Ramal do Lontra e Granodiorito Presidente Kennedy) distribuídos ao longo da borda oriental desta megaestrutura. Entretanto, na região de Paraíso do Tocantins, os corpos granitóides brasilianos são mais numerosos e constituem os chamados "granitóides Santa Luzia". Eles ocorrem principalmente na forma de pequenos stocks, diques, veios e lentes intrusivos nos biotita xistos e quartzitos do Grupo Estrondo (Proterozóico superior), concordantes ou não com a foliação desses metassedimentos. Tais relações espaciais sugerem uma natureza sin a tardi-tectônica para esses granitóides. Estudos petrográficos e geoquímicos revelaram que essas rochas são peraluminosas e consistem essencialmente em granodioritos, monzogranitos e granitos pegmatóides, possivelmente resultantes da diferenciação de um mesmo magma original. As razõ̃es $\mathrm{K} / \mathrm{Rb}$ e $\mathrm{Rb} / \mathrm{Sr}$ variam pouco e mostram que os granitóides Santa Luzia provêm de magmas pouco fracionados gerados na crosta continental. Os teores de Ca e $\mathrm{Sr}$ e a razão inicial ${ }^{87} \mathrm{Sr}{ }^{86} \mathrm{Sr}=0,707$ apoiam esta hipótese e apontam o embasamento gnáissico (Complexo Colméia) como fonte principal desses magmas. A presença de encraves angulosos de xistos com contatos bruscos com os granitóides, sugere que os metassedimentos supracrustais tiveram uma participação apenas subordinada na formação desses magmas. Enfim, essas rochas apresentam um "trend" próximo ao dos granitos com baixo $\mathrm{Ca}$ e, no diagrama $\mathrm{Rb}-(\mathrm{Y}+\mathrm{Nb})$, plotam no campo dos granitos de arcos vulcânicos, porém próximo ao limite do campo dos granitos sin-colisionais. Acredita-se, portanto, que os granitóides Santa Luzia pertencem a essa última categoria.

Palavras chaves: peraluminosos, magmatismo, Cráton Amazônico, granitóides.

INTRODUÇÃO Na região de Paraíso do Tocantins, porção meridional do Cinturão Araguaia, rochas granitóides formam inúmeros pequenos stocks, diques, veios e lentes, concordantes ou não com as estruturas impressas nos metassedimentos do Grupo Estrondo. Pequenos afloramentos de granitos pegmatóides, localizados a sudeste e a sul de Paraíso do Tocantins, foram englobados nos granitóides Santa Luzia por Costa et al. (1983) com base em semelhanças macroscópicas. Esses granitóides foram datados pelos métodos $\mathrm{Rb} / \mathrm{Sr}$ (Lafon \& Avelar, dados inéditos) e por evaporação de $\mathrm{Pb}$ em zircão (Moura 1992) fornecendo idades de $665 \pm 12 \mathrm{Ma}$ e $583 \pm 39 \mathrm{Ma}$, respectivamente. Essas rochas foram chamadas inicialmente de "Suíte Santa Luzia" (Costa et al. 1983). Neste trabalho, adota-se a denominação de "granitóides Santa Luzia", uma vez que os dados disponíveis não são suficientes para a caracterização de uma suíte. As melhores exposições desses granitóides conhecidas até o momento encontram-se nos arredores da vila Sta. Luzia e a NW do povoado de Barrolândia, numa pedreira abandonada (Fig. 1). Outras ocorrências de menor extensão estão presentes ao longo darodoviaBR-153 (Belém-Brasília) entre essas duas localidades. Mineralizações com berilo, turmalina, granada e moscovita estão presentes nas porções pegmatóides dessas rochas, bem como em corpos pegmatíticos e em veios de quartzo associados.

O CINTURÃO ARAGUAIA Considerado como uma área de colisão continental (Caputo 1984, Hasui \& Costa 1990), o Cinturão Araguaia apresenta-se como uma extensa faixa de rochas de direção submeridiana de mais de $1000 \mathrm{~km}$ de comprimento e até $150 \mathrm{~km}$ de largura (Dall'Agnol et al. 1988). A unidade litoestratigráfica de maior expressão areai deste cinturão é o Supergrupo Baixo Araguaia (SGBA) (Abreu 1978), constituída pelos Grupos Estrondo na base e Tocantins no topo. O primeiro compreende as Formações Morro do Campo (base) e Xambioá (topo) e ocorre na parte oriental do Cinturão Araguaia, sendo a unidade afetada por metamorfismo de mais alto grau - fácies xisto verde alto a anfibolito médio (Dall'Agnol et al. 1988). A Formação Morro do Campo é composta de ortoquartzitos, metaconglomerados, 


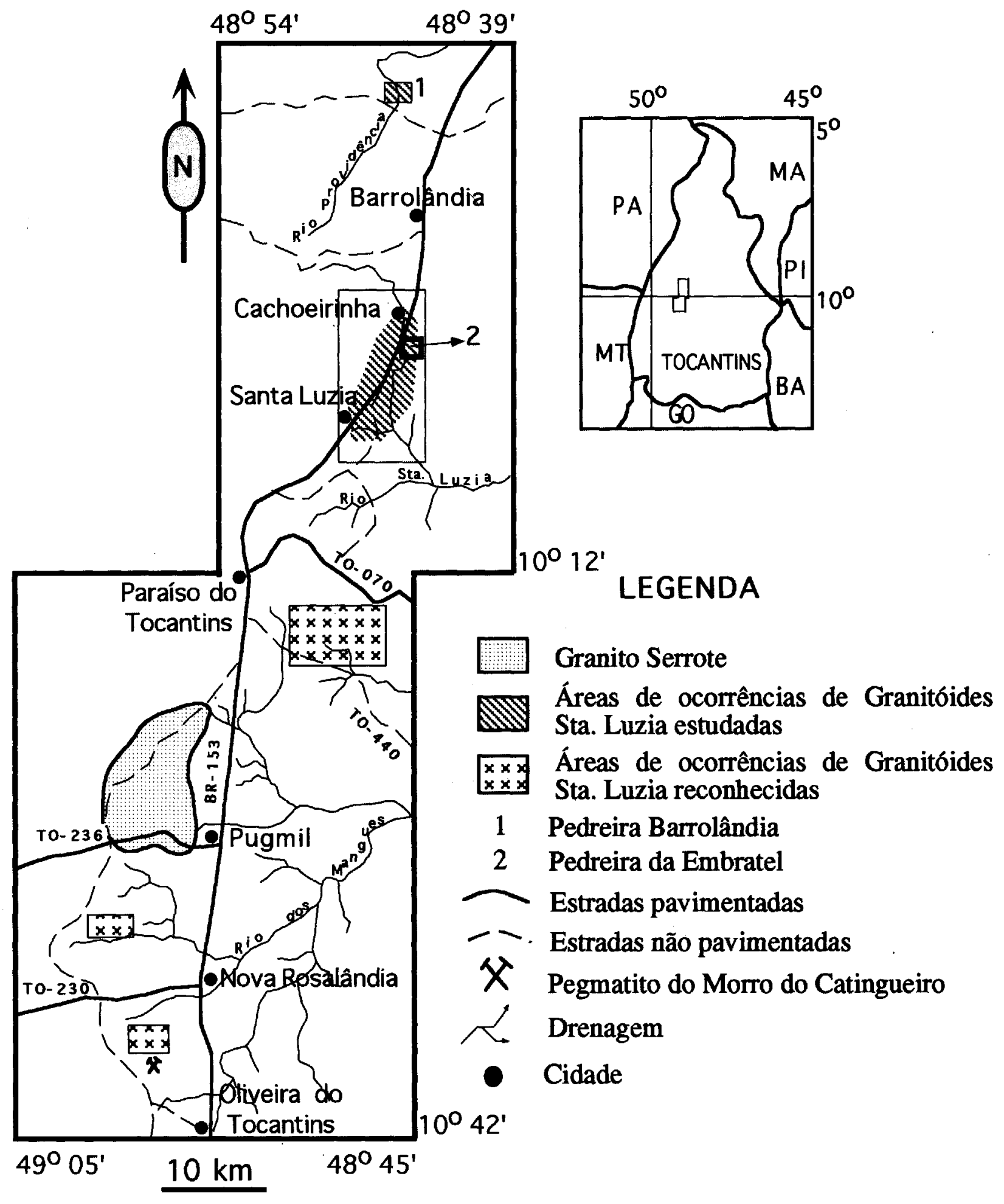

Figura 1 - Localização da região estudada e das principais áreas de ocorrências de granitóides Santa Luzia (modificado de Costa et al 1983).

Figure 1 - Location map of the studied region and of the main Santa Luzia granitoid occurrences (modified from Costa et al. 1983).

moscovita -quartzo xistos, biotita-quartzo xistos e micaxistos grafitosos com ocorrências locais de cianita, fibrolita e granada. A Formação Xambioá repousa concordantemente sobre a Formação Morro do Campo e é constituída essencialmente por micaxistos com intercalações de quartzitos, xistos grafitosos, anfibolitos e mármores.
O Grupo Tocantins ocupa as porções central e ocidental do Cinturão Araguaia, sendo a unidade de maior extensão areal. É composto pelas Formações Pequizeiro e Couto Magalhães. A primeira é constituída predominantemente por cloritamoscovita xistos com intercalações de filitos, quartzitos e xistos carbonáticos. A segunda consiste em filitos e ardósias 
com intercalações de quartzitos, metarenitos, metarcósios, metagrauvacas, metachert, metassiltitos, filitos carbonáticos, metargilitos e calcários (Gorayeb 1981, Herz et al. 1989).

Próximo à borda oriental do Cinturão Araguaia, no domínio do Grupo Estrondo, rochas do embasamento estão expostas nos núcleos de estruturas dômicas alinhadas segundo a direção N-S. As principais unidades presentes são: (1) o Complexo Colméia (Costa 1980), formado por ortognaisses arqueanos de composição tipicamente trondhjemítica (Santos et al. 1984, Teixeira et al. 1985, Dall'Agnol et al. 1988, Moura 1992), por

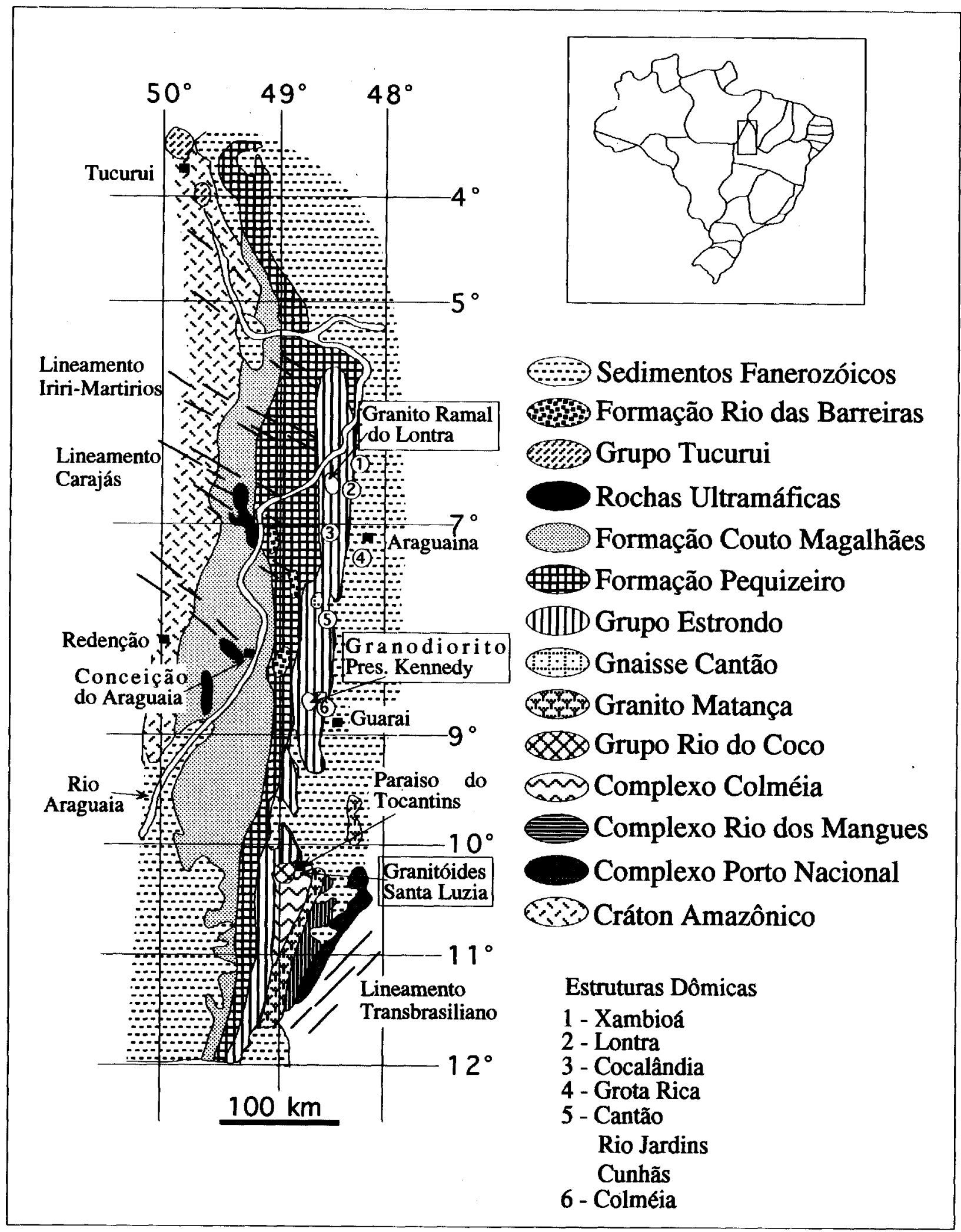

Figura 2 - Mapa geológico simplificado do Cinturão Araguaia (modificado de Moura 1992).

Figure 2 - Simplified geologic map of the Araguaia Belt (modified from Moura 1992). 
vezes acompanhados por gnaisses de composição granítica e anfibolitos subordinados e, (2) o Gnaisse Cantão (Souza 1984), do Paleoproterozóico, constituído por ortognaisses granodioríticos, sienograníticos e monzograníticos» com predomínio dos últimos.

Corpos granitóides intrusivos nos metassedimentos do Grupo Estrondo são pouco abundantes na porção norte do Cinturão Araguaia, onde apenas o Granito Ramal do Lontra (Macambira 1983), situado nas proximidades da estrutura do Lontra, e o Granodiorito Presidente Kennedy (Bulhões \& Dall'Agnol 1985), localizado a leste do domo de Colméia, possuem maior expressão. Na região de Paraíso do Tocantins, mais ao sul, rochas graníticas afloram mais amplamente. Essas rochas foram genericamente englobadas nos granitóides Santa Luzia (Costa et al 1983) (Fig. 2). A sul de Paraíso do Tocantins aflora um corpo de forma alongada na direção NNE-SSW e de composição granítica, constituindo a Serra do Serrote (Fig. 1). Apresenta granulação média a grossa nas porções centrais e fina nas bordas. Foi interpretado inicialmente como produto do magmatismo ácido que teria marcado a fase tardia da evolução do Complexo Colméia (Hasui et al. 1984). Entretanto, datações $\mathrm{Pb}-\mathrm{Pb}$ em zircão forneceram uma idade de $1851 \pm 41$ Ma para esse corpo (Sousa 1995).

Outro corpo granitóide de dimensões batolíticas é representado pelo Granitóide Matança (Costa et al 1983), localizado a SE da cidade de Paraíso do Tocantins, com aproximadamente $250 \mathrm{~km}$ de comprimento na direção NE-SW e 23 $\mathrm{km}$ de largura. É constituído por rochas de granulação grossa, de coloração rósea a cinza esbranquiçada e contém cristais de feldspato potássico de até $7 \mathrm{~cm}$ de comprimento, geralmente estirados e imersos em uma matriz fina, bandada e foliada (Hasui \& Costa 1990). A idade isocrônica Rb-Sr de $510 \pm 15$ Ma obtida para essas rochas pode corresponder à idade de cristalização ou ser devida a um rejuvenescimento isotópico durante o evento Brasiliano (Barradas et l 1992).

O grau do metamorfismo que afetou o Cinturão Araguaia aumenta de oeste para leste, variando de incipiente próximo ao Cráton Amazônico até atingir a fácies anfibolito médio no domínio do Grupo Estrondo (Dali' Agnol et al 1988). A idade do Cinturão Araguaia tem sido debatida ao longo dos anos. Entretanto, Moura (1992) efetuou datações $\mathrm{Pb}-\mathrm{Pb}$ em zircão provenientes de veios graníticos deformados e estirados, considerados como contemporâneos à estruturação deste cinturão, bem como em zircão de rochas graníticas (granitóides Santa Luzia) admitidas como formadas durante o clímax do metamorfismo que afetou essa unidade geotectônica. As idades obtidas confirmam que o evento Brasiliano (700-400 Ma) foi o principal responsável pelo desenvolvimento deste cinturão.

GRANITÓIDES SANTA LUZIA Modos de ocorrência e relação com a rocha encaixante Os granitóides Santa Luzia na região de Paraíso do Tocantins apresentam-se na forma de inúmeros pequenos stocks, diques, lentes e veios que cortam os micaxistos do Grupo Estrondo. Acredita-se que este modo de ocorrência é devido ao fato de tratar-se de zona(s) apical(is) de corpo(s) maior(es) não aflorantes. Nos arredores da vila Santa Luzia tal modo de ocorrência é particularmente bem exposto. No Morro Dois Amigos, próximo à vila Santa Luzia, um pequeno corpo pegmatítico com textura gráfica encontra-se injetado nos micaxistos da Formação Morro do Campo. Lentes e veios de rochas granitóides encontram-se amplamente distribuídos nas encostas desse mesmo morro. Num corte da rodovia BR-153 (Belém-Brasília), próximo à localidade de Cachoeirinha, lentes de rochas granitóides apresentam-se concordantes com a

Tabela 1 - Composições Modais dos granitóides Santa Luzia estudados.

Table 1 - Modal compositions of Santa Luzia granitoids.

\begin{tabular}{|c|c|c|c|c|c|c|c|c|c|c|c|c|c|c|c|c|}
\hline \multirow{3}{*}{$\begin{array}{l}\text { Área } \\
\text { Minerais }\end{array}$} & \multicolumn{11}{|c|}{ Vila Santa Luzia } & \multirow{3}{*}{$\begin{array}{c}\begin{array}{c}\text { corte BR- } \\
153\end{array} \\
\frac{\text { BuMvO }}{\text { CL-32 }}\end{array}$} & \multirow{2}{*}{\multicolumn{2}{|c|}{$\begin{array}{l}\text { Cachoeirimha } \\
\text { MvBMMG }\end{array}$}} & \multirow{2}{*}{\multicolumn{2}{|c|}{$\begin{array}{c}\begin{array}{c}\text { Pedreira } \\
\text { Barrolândia }\end{array} \\
\text { MvBMEG } \\
\end{array}$}} \\
\hline & \multicolumn{3}{|c|}{ GPg } & \multicolumn{2}{|c|}{ MvMZG } & \multicolumn{6}{|c|}{ MvBGGD } & & & & & \\
\hline & $\begin{array}{l}\mathrm{CL} \\
\mathbf{0 3 A} \\
\end{array}$ & $\begin{array}{l}\mathrm{CL} \\
08 \mathrm{~A} \\
\end{array}$ & CL-21 & CL-06 & CL-09 & CL-36 & CL-38 & $\begin{array}{l}\mathrm{Cl} \\
39 \mathrm{~A}\end{array}$ & $\begin{array}{l}\text { CL- } \\
39 D\end{array}$ & CLA1 & $\begin{array}{l}\text { CL- } \\
\text { 42D }\end{array}$ & & CL-18 & $\begin{array}{l}\mathrm{CL} \\
31 \\
\end{array}$ & $\begin{array}{l}\mathrm{CL} \\
24 \mathrm{~A}\end{array}$ & $\begin{array}{l}\mathrm{CL} \\
24 \mathrm{C} \\
\end{array}$ \\
\hline Quartzo & 39,0 & 31,3 & 48,0 & 31,6 & 23,7 & 21,5 & 26,2 & 28,5 & 34,8 & 25,4 & 33,3 & 30,9 & 25,1 & 30,0 & 20,0 & 28,2 \\
\hline Plag. & 17,5 & 32,5 & 7,3 & 26,0 & 34,9 & 49,5 & 46,8 & 47,5 & 46,7 & $\$ 2,0$ & 46,7 & 45,0 & 35,9 & 28,4 & 44,6 & 39,1 \\
\hline K-fsp. & 24,9 & 31,6 & 38,6 & 28,6 & 32,3 & 19,6 & 16,9 & 17,3 & 13,0 & 14,2 & 10,0 & 14,2 & 23,8 & 31,1 & 28,0 & 24,5 \\
\hline Biot. & - & - & - & - & 0,7 & 8,0 & 6,6 & 3,8 & 3,3 & 4,1 & 8,5 & 3,3 & 11,3 & 7,8 & 6,4 & 6,5 \\
\hline Musc. & 17,8 & 4,4 & 6,0 & 13,2 & 8,0 & 0,9 & 3,0 & 1,8 & 2,0 & 3,9 & 1,1 & 5,4 & 3,6 & 2,4 & 0,7 & 1,5 \\
\hline Acess. & 0,8 & - & - & 0,2 & - & 0,3 & 0,3 & 0,9 & - & 0,2 & 0,2 & 0,6 & 0,1 & 0,2 & - & - \\
\hline $\begin{array}{l}n^{\circ} \text { pontos } \\
\text { a } 100 \%\end{array}$ & 1000 & 1260 & 900 & 1300 & 1295 & 1300 & 1300 & 2000 & 1200 & 1500 & 1200 & 1296 & 1300 & 1300 & 1300 & 1300 \\
\hline Quarzo & 47,9 & 32,8 & 51,1 & 36,6 & 26,0 & 23,7 & 29,1 & 30,5 & 36,8 & 27,7 & 37,0 & 34,3 & 29,6 & 33,5 & 21,6 & 30,7 \\
\hline Plag & 21,5 & 34,01 & 7,7 & 30,1 & 38,4 & 54,6 & 52,0 & 50,9 & 49,4 & 56,7 & 51,8 & 49,9 & 42,3 & 31,7 & 48,1 & 42,5 \\
\hline $\begin{array}{l}\text { K-fisp } \\
100 \%\end{array}$ & 30,6 & 33,1 & 41,1 & 33,2 & 35,5 & 21,6 & 18,8 & 18,6 & 13,7 & 15,5 & 11,1 & 15,7 & 28,1 & 34,7 & 30,2 & 26,7 \\
\hline Quartzo & 47,9 & 32,8 & 51,1 & 36,6 & 25,8 & 21,8 & 27,2 & 29,4 & 35,6 & 26,5 & 33,8 & 33,1 & 26,1 & 30,8 & 20,2 & 28,7 \\
\hline $\mathbf{P l}+\mathbf{K} \mathbf{f}$ & 52,1 & 67,2 & 48,9 & 63,3 & 73,3 & 70,1 & 66,0 & 66,7 & 61,0 & 69,2 & 57,5 & 63,4 & 62,1 & 61,1 & 73,3 & 64,7 \\
\hline máficos & $=$ & $=$ & - & $=$ & 0,7 & 8,1 & 6,8 & 3,9 & 3,4 & 4,3 & 8,6 & 3,5 & 11,7 & 8,0 & 6,4 & 6,6 \\
\hline
\end{tabular}

$\mathrm{GPg}=$ Granito Pegmatóide, $\mathrm{MZG}=$ Monzogranito, $\mathrm{GD}=$ Granodiorito, $\mathrm{Mv}=$ Muscovita, $\mathrm{Bt}=$ Biotita, $\mathrm{PI}=\mathrm{Plagioclasio}, \mathrm{Kf}=\mathrm{Feldspato}$ potássico,

Acess. = Acessórios 

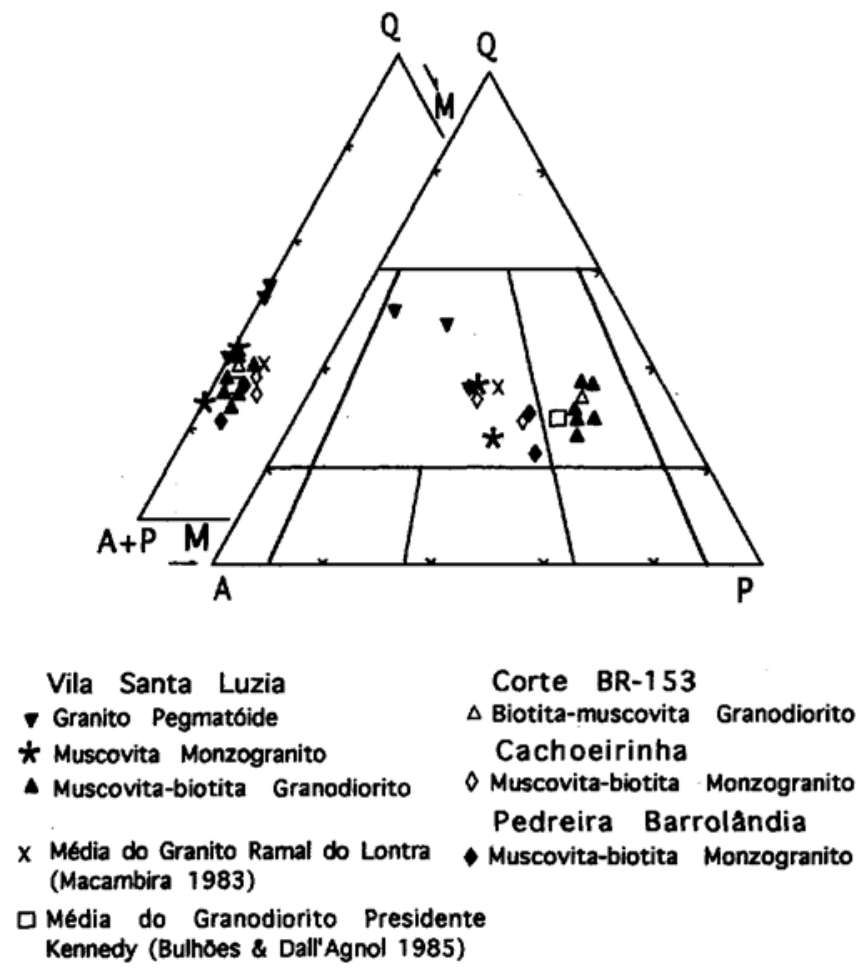

Figura 3 - Diagramas $Q A P$ e Q-(A+P)-Mpara os granitóides Santa Luzia e outros granitóides da porção norte do Cinturão Araguaia.

Figure 3 - QAP and Q-(A+P)-M diagrams for Santa Luzia granitoids and others granitoids from the northern portion of the Araguaia Belt.

xistosidade da formação encaixante. A noroeste de Barrolândia, a exploração de uma pedreira expôs melhor os granitóides Santa Luzia. Tanto nesta pedreira como na da torre da Embratel (Fig. 1), foram observados encraves angulosos de xistos dentro dos corpos intrusivos. Enfim, foram distinguidas no campo diferentes gerações de rochas graníticas variando de tipos de granulação fina até tipos pegmatóides.

Aspectos macroscópicos Macroscopicamente, os granitóides Santa Luzia são muito semelhantes. Exibem uma coloração acinzentada a rosa-acinzentada e uma granulação muito variável, desde fina até pegmatóide. Observam-se quartzo, K-feldspato, plagioclásio, biotita e muscovita. Localmente distinguem-se granitos pegmatóides ocorrendo nas cúpulas de pequenos stocks, ou na forma de lentes, diques e massas. Eles geralmente cortam as rochas de granulação mais fina e apresentam uma coloração rosada e uma granulação média a pegmatóide. Neles podem ser identificados K-feldspato, quartzo, plagioclásio e muscovita como minerais essenciais. Acessoriamente encontra-se turmalina preta na forma de cristais prismáticos milimétricos isolados ou formando massas intercrescidas com o quartzo. Cristais milimétricos de granada avermelhada e de berilo verde-azulado também estão presentes, geralmente inclusos nos cristais de K-feldspato.

Aspectos microscópicos Foram submetidas à análise modal 16 amostras de granitóides Santa Luzia (Tab.1). Com base nesses dados e no diagrama Q-A-P (Streckeisen 1976), foram distinguidos os seguintes litotipos: (1) moscovita-bi- otita granodiorito, (2) biotita -moscovita granodiorito, (3) moscovita-biotita monzogranito, (4) moscovita monzogranito $\mathrm{e},(5)$ granito pegmatóide. $\mathrm{O}$ diagrama $\mathrm{Q}-(\mathrm{A}+\mathrm{P})-\mathrm{M}$ mostra que 0 conteúdo percentual de minerais máficos dessas rochas varia de 0 a $10 \%$, sendo representados por biotita, apatita, titanita e zircão. (Fig. 3). Os diferentes granitóides Santa Luzia apresentam basicamente as mesmas fases minerais havendo, entretanto, variações percentuais significativas entre elas. Quartzo, oligoclásio, microclina, biotita e moscovita são os minerais essenciais. Apatita, zircão, titanita, turmalina e granada constituem os minerais acessórios primários. Sericita, clorita, epidoto e, mais raramente, opacos são os principais minerais de alteração.

GRANODIORITOS Nessas rochas a textura inequigranular é mais freqüente. Quartzo, plagioclásio e microclina são os minerais mais abundantes e seus cristais são os mais desenvolvidos. Cristais anédricos de quartzo mostram contatos irregulares/denteados com o plagioclásio. O plagioclásio (An 25-20), apresenta macias, às vezes, levemente encurvadas. A microclina exibe maclamento albita-periclina predominante $\mathrm{e}$ alguns cristais mostram intercrescimento micropertítico na forma de flames. A biotita, comumente em cristais subédricos $1 \mathrm{~mm}$, aparece por vezes levemente encurvada. A moscovita geralmente acompanha a biotita e apresenta dimensões semelhantes, o que sugere a formação contemporânea dos dois minerais. Como minerais acessórios primários aparecem: (1) a apatita, em pequenos cristais anédricos a subédricos geralmente em contato com a biotita ou o plagioclásio; (2) o zircão em diminutos cristais subédricos inclusos na biotita na qual desenvolvem halos pleocróicos; (3) a titanita (subédrica) em cristais $(0,1 \mathrm{~mm})$ associados à biotita, microclina e ao quartzo. Clorita e oxido de ferro ocorrem como minerais de alteração em alguns cristais de biotita. A sericita, resultante da alteração do plagioclásio, é mais abundante nos núcleos do que nas bordas dos cristais e geralmente acompanha os planos de clivagem e de maclamento ou, ainda, preenche fraturas. $\mathrm{O}$ epidoto, em cristais anédricos de menos de $0,1 \mathrm{~mm}$ de comprimento, também provém do plagioclásio.

MONZOGRANITOS A textura granular hipidiomórfica é predominante nessas rochas, sendo os cristais de microclina, quartzo e plagioclásio os mais desenvolvidos. A granulação é variável com predominância de média a grossa.

A microclina constitui de 24 a $32 \%$ da rocha e ocorre em cristais anédricos, raramente subédricos, cujas dimensões variam de 1,0 a 4,0 mm. O maclamento "xadrez" típico é dominante; os cristais comportam, por vezes, finas lamelas micropertíticas bem desenvolvidas e, com freqüência, bordas de reação nos contatos com o plagioclásio. O quartzo representa em média $27 \%$ da rocha. Ocorre em cristais anédricos com dimensões variando de 1,1 a 4,5 mm. Exibe extinção ondulante marcante. Está presente ainda na forma vermicular ou de pequenas gotas como constituinte das mirmequitas, ou como pequenas inclusões arredondadas nos cristais de microclina e de plagioclásio. O plagioclásio aparece em cristais anédricos a subédricos de dimensões variando de 1,2 a 3,6 $\mathrm{mm}$. Trata-se de oligoclásio sódico (An 18-14) maclado segundo a lei da albita e albita-carlsbad. O desenvolvimento de sericita e argilo-minerais é muito comum. A biotita ocorre normalmente na forma de cristais subédricos de 1,0 a 2,0 mm de comprimento e altera-se localmente para clorita e oxido de ferro. A muscovita é subédrica e geralmente associada à biotita. Apresenta comumente bordas corroídas. Ocorre também como produto de alteração do plagioclásio na forma de finas lamelas. Nos muscovita monzogranitos da vila Santa Luzia, a muscovita é o mineral micáceo predominante e constitui em média em torno de $11 \%$ da rocha. Apatita, zircão, turmalina e, mais raramente, opacos são os principais 
acessórios primários. Clorita, epidoto e sericita são os minerais de alteração mais comuns encontrados nessas rochas.

GRANITO PEGMATÓIDE Nesta rocha, a textura porfirítica é predominante, destacando-se fenocristais médios a grossos de microclina pertítica em matriz fina. Cristais de plagioclásio fortemente sericitizados mostram intercrescimentos mirmequíticos do tipo vermicular bem desenvolvidos no contato com fenocristais de microclina.

O quartzo constitui 31 a $48 \%$ da rocha, apresenta-se em cristais anédricos de 1,5 a $3,0 \mathrm{~mm}$ e exibe extinção ondulante. Está presente também na forma de pequenos grãos anédricos inclusos nos fenocristais de microclina. Constitui ainda intercrescimentos mirmequíticos com o plagioclásio, assumindo a forma vermicular ou de pequenas bolhas. A microclina apresenta-se na forma de fenocristais, anédricos, com tamanho variando de 2,0 a 7,0 mm e exibindo o maclamento albita-periclina típico. Constitui em média $32 \%$ da rocha e mostra lamelas pertíticas do tipo flame, film e string. De um modo geral os cristais de microclina apresentam-se pouco alterados. Seus contatos com os cristais de quartzo e de plagioclásio são irregulares. Os cristais de plagioclásio (An 16-12) são anédricos a subédricos e maclados segundo a lei da albita e albita carlsbad. A muscovita compõe de 4 a $18 \%$ da rocha e ocorre em cristais subédricos cujo tamanho varia de 1,0 a 3,5 $\mathrm{mm}$. Encontra-se também na forma de finas lamelas resultantes da alteração do plagioclásio. A apatita é o mineral acessório primário mais freqüente e ocorre em cristais anédricos $(1,0$ $\mathrm{mm}$ ), geralmente inclusos no plagioclásio. A granada aparece em grãos anédricos em contato com a microclina e geralmente exibe fraturas preenchidas por argilo-minerais. A turmalina forma cristais anédricos a subédricos de até 7,0 mm de comprimento, fraturados e de coloração verde-azulada. Como minerais de alteração predominam sericita e argilo-minerais, sobretudo, na parte central dos cristais de plagioclásio.

GEOQUÍMICA Sete amostras foram analisadas para elementos maiores e os elementos traços $\mathrm{Rb}, \mathrm{Sr}, \mathrm{Zr}, \mathrm{Nb}$ e $\mathrm{Y}$. A procedência dessas amostras é indicada nas Tabelas 1 e 2 . $\mathrm{SiO}_{2}, \mathrm{TiO}_{2}, \mathrm{Al}_{2} \mathrm{O}_{3}, \mathrm{Fe}_{2} \mathrm{O}_{3}, \mathrm{FeO}$ e $\mathrm{P}_{2} \mathrm{O}_{5}$ foram determinados por volumetria, gravimetria e colorimetria, enquanto que as concentrações de $\mathrm{CaO}, \mathrm{Na}_{2} \mathrm{O}, \mathrm{K}_{2} \mathrm{O}$ e $\mathrm{MgO}$ foram obtidas por espectrometria de absorção atômica. Os teores dos elementos traços foram determinados por fluorescência de raios-X. Todas as análises foram realizadas nos laboratórios da UFPA. Os resultados dessas análises constam da Tabela 2. São também plotadas nos diagramas de variação amostras de outros granitóides aflorantes na porção norte do Cinturão Araguaia para comparação com os granitóides Santa Luzia.

Elementos maiores Dentre os litotipos distinguidos, foram estudados geoquimicamente: moscovita-biotita granodiorito, biotita-moscovita granodiorito, moscovita-biotita monzogranito e granito pegmatóide. Os quatro litotipos enfocados apresentam diferenças muito pequenas nos seus teores de $\mathrm{SiO}_{2}(71$ a $73 \%)$ e conteúdos de $\mathrm{Al}_{2} \mathrm{O}_{3}$ relativamente elevados (13a 15\%). O caráter leucocrático dessas rochas é sublinhado pelos baixos conteúdos de $\mathrm{FeO}, \mathrm{Fe}_{2} \mathrm{O}_{3}, \mathrm{MgO}$ e $\mathrm{TiO}_{2}$.

Os diagramas de Harker (Fig. 4) mostram que os teores de $\mathrm{SiO}_{2}$ não refletem uma seqüểncia lógica de diferenciação magmática (granodiorito-monzogranito-granito pegmatóide). Com o aumento da silica, o teor de $\mathrm{K}_{2} \mathrm{O}$ tende a diminuir nos granodioritos enquanto que nos monzogranitos observa-se, ao contrário, um leve enriquecimento neste oxido. A con-centração de $\mathrm{Na}_{2} \mathrm{O}$ tende a diminuir em ambas as associações com o aumento do teor de silica, porém o decréscimo é maior nos granodioritos. As concentrações de $\mathrm{MgO}, \mathrm{FeO}+\mathrm{Fe}_{2} \mathrm{O}_{3}$ e $\mathrm{CaO}$ tendem claramente a diminuir com o aumento da silica, em-
Tabela 2 - Composições químicas e normas CIPW dos granitóides Santa Luzia.

Table 2 - Chemical compositions and CIPW norms of the Santa Luzia granitoids.

\begin{tabular}{|c|c|c|c|c|c|c|c|c|}
\hline & \multicolumn{4}{|c|}{ Vilh Smte Luria } & \multirow{2}{*}{$\begin{array}{c}\text { corte } \\
\text { BR-253 }\end{array}$} & \multirow{2}{*}{$\begin{array}{c}\text { Cechoerinthe } \\
\text { CL-18 }\end{array}$} & \multirow{2}{*}{$\frac{\text { Barrolindia }}{\text { CL-24 }}$} & \multirow[t]{2}{*}{ A } \\
\hline ÓxIDOS & CL-21 & CL-36 & CL-38 & CL-4I & & & & \\
\hline $\mathrm{SiO}_{2}$ & 73,77 & 71,95 & 73,34 & 71,89 & 73,28 & 71,66 & 71,52 & 72,08 \\
\hline $\mathrm{TO}_{2}$ & 0,10 & 0,24 & 0,37 & 0,23 & 0,20 & 0,33 & 0,36 & 0,37 \\
\hline $\mathrm{Al}_{2} \mathrm{O}_{3}$ & 15,20 & 13,99 & 13,12 & 15,12 & 15,28 & 13,20 & 15,08 & 13,86 \\
\hline $\mathrm{Fe}_{2} \mathrm{O}_{3}$ & 0,41 & 1,55 & 2,03 & 1,67 & 1,04 & 2,17 & 1,83 & 2,53 \\
\hline $\mathbf{F} \boldsymbol{O}$ & 0,14 & 0,54 & 0,93 & 0,76 & 0,43 & 0,86 & 0,92 & - \\
\hline MnO & - & $\longrightarrow$ & $\rightarrow$ & - & $\longrightarrow$ & - & - & 0,06 \\
\hline MsO & 0,07 & 0,40 & 0.50 & 0,37 & 0,34 & 0,86 & 0,47 & 0,52 \\
\hline $\mathrm{CaO}$ & 0,63 & 1,64 & 1,64 & 1,46 & 1,33 & 1,65 & 1,68 & 1,33 \\
\hline $\mathrm{Na}_{2} \mathrm{O}$ & 3,20 & 4,17 & 4,04 & 4,39 & 3,85 & 2,71 & 3,75 & 3,08 \\
\hline $\mathrm{K}_{2} \mathrm{O}$ & 3,95 & 2,96 & 2,40 & 2,52 & 2,63 & 5,10 & 4,05 & 5,46 \\
\hline $\mathrm{P}_{2} \mathrm{O}_{5}$ & 0,10 & 0,10 & 0,10 & 0,12 & 0,25 & 0,10 & 0,10 & 0,18 \\
\hline $\mathrm{H}_{2} \mathrm{O}+$ & $1, \infty$ & 0,86 & 0,62 & 0,83 & 0,94 & 0,50 & 0,40 & 0,53 \\
\hline $\mathrm{H}_{2} \mathrm{O}$ - & 0,05 & 0,03 & 0,06 & 0,04 & 0,08 & 0,02 & 0,02 & - \\
\hline Total & 98,62 & 98,43 & 99,15 & 99,36 & 99,65 & 99,08 & 100,18 & 100,6 \\
\hline $\mathrm{Ne}_{2} \mathrm{O} / \mathbf{K}_{2} \mathrm{O}$ & 0,81 & 1,41 & 1,68 & 1,74 & 1,46 & 0,53 & 0,93 & 0,57 \\
\hline $\mathrm{Ne}_{2} \mathrm{O} / \mathrm{CaO}$ & 5,08 & 2,54 & 2,46 & $\mathbf{3 , 0 0}$ & 2,89 & 1,64 & 2,23 & 2,32 \\
\hline \multicolumn{9}{|l|}{ TRAÇOS } \\
\hline $\mathbf{R D}$ & 157 & 119 & 109 & 150 & 102 & 160 & 169 & - \\
\hline st & 114 & 356 & 244 & 319 & 164 & 375 & 430 & - \\
\hline $\mathbf{z x}$ & 38 & 161 & 160 & 184 & 122 & 125 & 216 & - \\
\hline $\mathrm{Nb}$ & 13 & 10 & $<5$ & 14 & $<5$ & 10 & 17 & - \\
\hline $\mathbf{Y}$ & 1 & 9 & 9 & 8 & 10 & 10 & 13 & - \\
\hline $\mathbf{R b} / \mathbf{s} \mathbf{s}$ & 1,38 & 0,33 & 0,45 & 0,47 & 0,62 & 0,43 & 0,38 & 一 \\
\hline $\mathbf{R} / \mathbf{R b}$ & 208 & 206 & 183 & 139 & 214 & 264 & 206 & - \\
\hline \multicolumn{9}{|c|}{ NORMAS CIPW } \\
\hline$Q z$ & 39,73 & 32,81 & 36,70 & 33,33 & 38,42 & 31,54 & 29,74 & - \\
\hline$\alpha$ & 23,97 & 18,06 & 14,57 & 15,26 & 15,84 & 30,89 & 24,25 & - \\
\hline $\mathbf{A b}$ & 27,81 & 36,43 & 35,12 & 38,06 & 33,21 & 23,50 & 32,15 & - \\
\hline An & 2,54 & 7,73 & 7,69 & 6,62 & 5,06 & 7,72 & 7,78 & - \\
\hline c n & 4,88 & 1,24 & 1,15 & 2,85 & 4,39 & 0,48 & 1,76 & - \\
\hline by & 0,57 & 2,75 & 3,43 & 2,83 & 194 & 4,59 & 3,05 & - \\
\hline Mn & 0,08 & 0,30 & 0,39 & 0,32 & 0,20 & 0,42 & 0,35 & - \\
\hline n & 0,20 & 0,47 & 0,72 & 0,45 & 0,39 & 0,64 & 0,69 & 一 \\
\hline Ap & 0.22 & 0,23 & 0.22 & 0,27 & 0,56 & 0,22 & $0,2,2$ & - \\
\hline Ab/Or & 1,16 & 2,01 & 2,41 & 2,49 & 2,09 & 0,76 & 1,32 & - \\
\hline
\end{tabular}

A = média de 72 granitos segundo Nockolds apua Wedepohl (1969)

CL-21 =, Granito Pegmatóide

CL-36, 38,41 = Muscovita-biotita Granodioritos

CL-32 = Biotita-muscovita Granodiorito

CL-18,24 = Muscovita-biotita Monzogranitos

Óxidos $=\%$ em peso, elementos traços $=$ ppm

bora duas amostras (CL-18 e CL-38) mostrem um comportamento anômalo em relação a este "trend" geral, refletindo o seu enriquecimento em máficos (cf. Tab. I). As concentrações de $\mathrm{Al}_{2} \mathrm{O}_{3}$ nos diferentes litotipos formam dois patamares distintos, sendo um deles com teores de 13,12; 13,99 e 13,20 $\%$ (CL-38, CL-36 e CL-18) e outro com teores de 15,08; 15,12 e $15,28 \%$ (CL-24, CL-41 e CL-32).

$\mathrm{O}$ diagrama $\mathrm{Na}_{2} \mathrm{O} \times \mathrm{K}_{2} \mathrm{O}$ (Fig. 5a) mostra que as concentrações desses óxidos nos granodioritos sofrem poucas variações, sendo relativamente ricas em sódio e tendo razões $\mathrm{Na}_{2} \mathrm{O}$ / $\mathrm{K}_{2} \mathrm{O}$ bastante elevadas $(1,4)$. Por outro lado, nos monzogranitos, ambos os óxidos apresentam concentrações muito variáveis e, sendo essas rochas mais ricas em potássio, apresentam razões $\mathrm{Na}_{2} \mathrm{O} / \mathrm{K}_{2} \mathrm{O}$ l. No granito pegmatóide, por sua vez, a razão $\mathrm{Na}_{2} \mathrm{O} / \mathrm{K}_{2} \mathrm{O}$ é intermediária as das amostras de monzogranitos.

Os teores de $\mathrm{CaO}$ são moderados e variam entre 1,33 e 1,64 $\%$ nos granodioritos e entre 1,65 e $1,68 \%$ nos monzogranitos. 

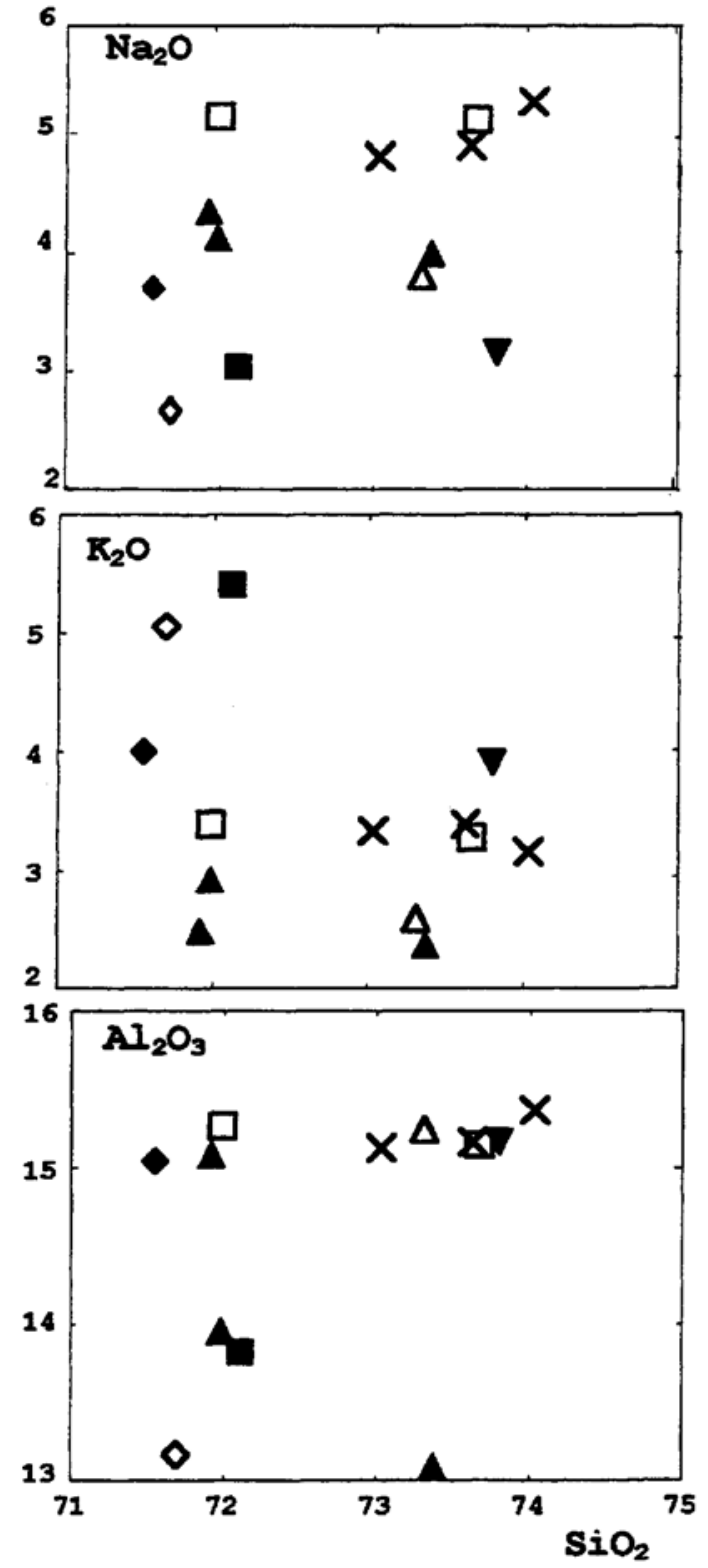
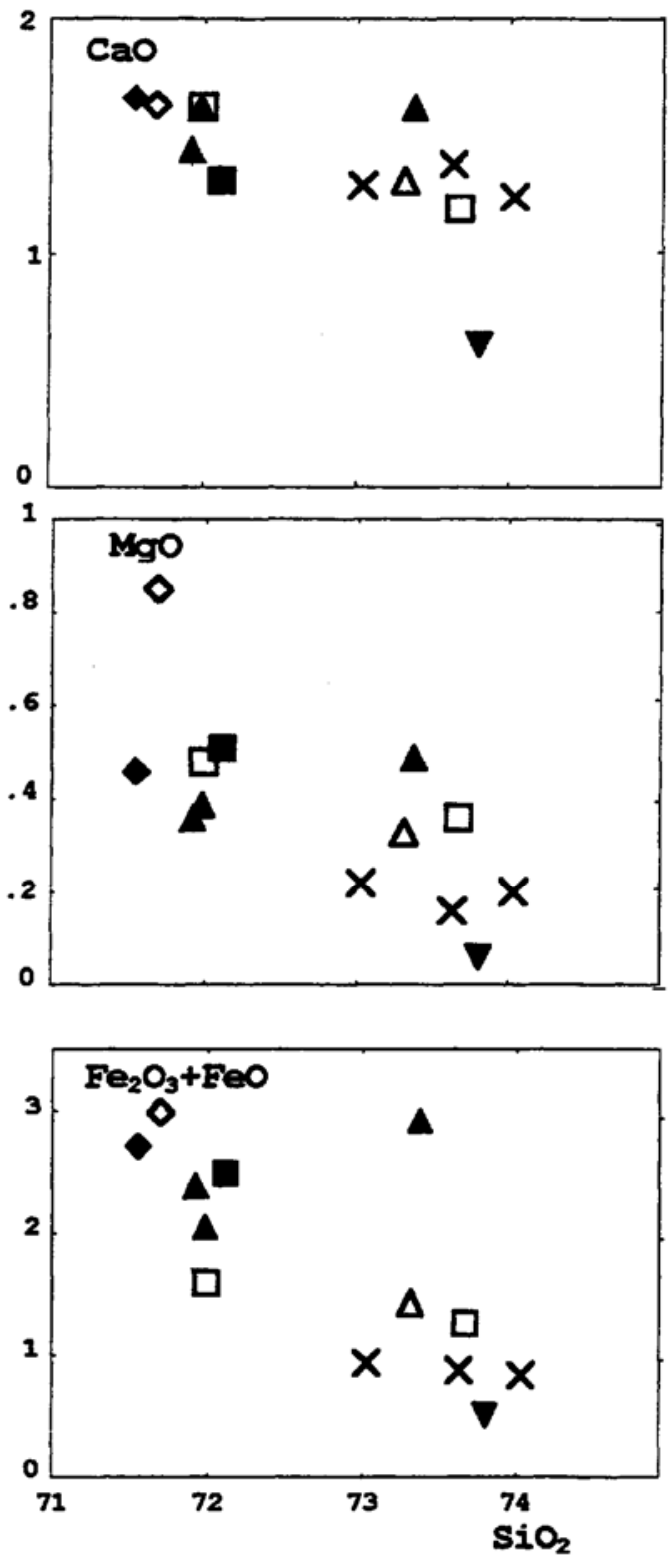

\section{( $\nabla$ )Granito Pegmatóide (vila Sta. Luzia)}

( $\Delta$ )Muscovita-biotita Granodiorito (vila Sta. Luxia)

( $\Delta$ )Biotita-muscovita Granodiorito (corte da BR-153)

( $\diamond)$ Muscovita-biotita Monzogranito (Cachoeirinha)

( $\bullet$ )Muscovita-biotita Monzogranito (Barrolândia)

( $\square$ )Granodiorito Presidente Kennedy (Dall'Agnol et al., 1988)

( X)Granito Ramal do Lontra (Macambira, 1983)

( ( ) Média de 72 granitos segundo Nockolds apud Wedepohl (1969)

Figura 4 - Diagramas de variação Oxidos $x \mathrm{SiO}_{2}(\%$ em peso) dos granitóides Santa Luzia e de outros granitóides da porção norte do Cinturão Araguaia.

Figure 4 - Oxides x $\mathrm{SiO}_{2}$ diagrams (wt \%) of the Santa Luzia granitoids and others granitoids from the northern portion of the Araguaia Belt.

São, portanto, um pouco superiores à média dos granitos segundo Nockolds (apud Wedepohl 1969) que é de 1,33\%. $\mathrm{O}$ granito pegmatóide contém pouco $\mathrm{CaO}(0,63 \%)$. No diagrama $\mathrm{CaO}-\mathrm{Na}_{2} \mathrm{O}-\mathrm{K}_{2} \mathrm{O}$ (Fig. 5b), os três litotipos são bem discriminados, ressaltando-se os seus baixos conteúdos de cálcio. O conjunto de rochas tende a seguir, de uma maneira geral, o trend aos granitos com baixo cálcio (Breaks \& Moore Jr. 1992).

Dados normativos Os granodioritos apresentam um teor de quartzo normativo em torno de $35 \%$, enquanto que nos 


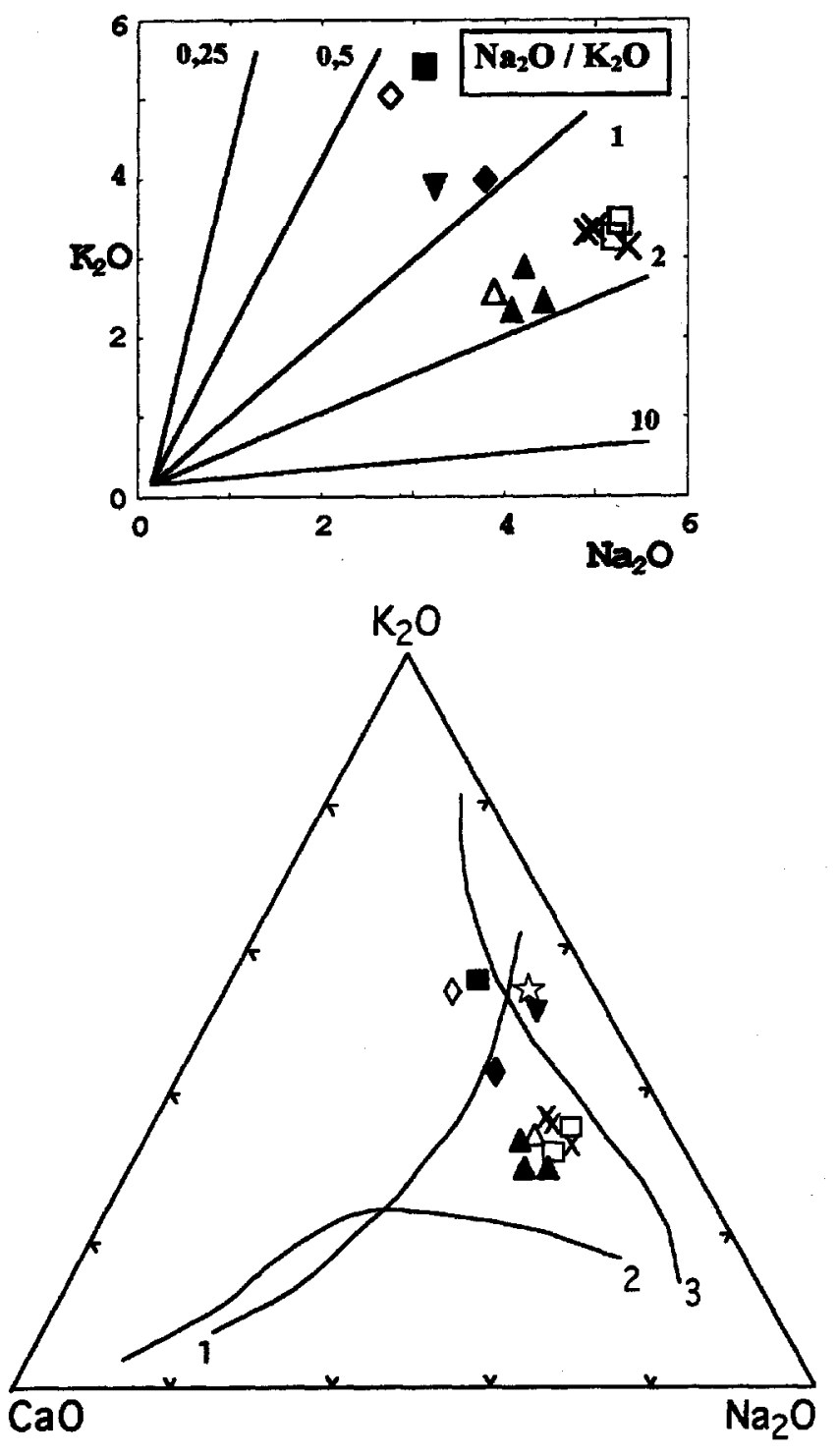

Figuras 5 - Diagramas (a) $\mathrm{K}_{2} \mathrm{O} \times \mathrm{Na}_{2} \mathrm{O}$ e (b) $\mathrm{CaO}-\mathrm{Na}_{2} \mathrm{O}-\mathrm{K}_{2} \mathrm{O}$ (\% em peso) para os granitóides Santa Luzia e outros granitóides da porção norte do Cinturão Araguaia (Símbolos conforme Fig. 4). Na figura $5 b$ os trends cálcico-alcalino (1) e trondhjemitico (2) segundo Nockolds \& Allen (1953) e Barker \& Arth (1976) respectivamente, os trends dos granitos com baixo Ca (3) segundo Breaks \& Moore Jr. (1992) e a estrela corresponde à média dos granitos com baixo Ca segundo Turekian \& Wedepohol (1961). Figures 5 - (a) $\mathrm{faO} \times \mathrm{Na}_{2} \mathrm{O}$ and (b) $\mathrm{CaO}-\mathrm{Na}_{2} \mathrm{O}-\mathrm{K}_{2} \mathrm{O}$ diagrams (wt \%) for Santa Luzia granitoids and others granitoids from the northern portion of the Araguaia Belt (Symbols as in Fig. 4). In figure 5b the calk-alkaline (1) and trondhjemitic (2) trends are according to Nockolds \& Allen (1953) and Barker \& Arth (1976) respectively, the low-Ca granites trend (3) according to Breaks \& Moore Jr. (1992), and the star corresponds to the average low-Ca granites according to Turekian \& Wedepohl (1961).

monzogranitos este teor é mais baixo, em torno de $31 \%$. O granito pegmatóide contém $39 \%$ de quartzo normativo.

Os teores de ortoclásio normativo são mais elevados nos monzogranitos $(24,25$ e $30,89 \%)$ e no granito pegmatóide $(23,97 \%)$ do que nos granodioritos $(14,5$ a $18,0 \%)$. O conteúdo de anortita normativa é muito baixo no granito pegmatóide $(2,54 \%)$ e oscila em torno de $7,5 \%$ nas outras duas associa- ções, com exceção da amostra CL-32 na qual alcança apenas $5 \%$. O corindo normativo é mais elevado no granito pegmatóide $(4,88 \%)$ e bastante variável nos outros litotipos (de 0,48 a $4,39 \%$ ). Os valores mais elevados estão refletidos na ocorrência expressiva de muscovita e/ou granada nessas rochas.

As amostras estudadas localizam-se dentro do campo definido para as rochas graníticas (Winkler 1979). Granodioritos e monzogranitos possuem valores de An muito próximos, porém mostram diferenças significativas nos conteúdos de $\mathrm{Ab}$ e Or. Esses dois litotipos se distinguem, em particular, por valores diferentes da razão $\mathrm{Ab} / \mathrm{Or}$ (Tabela 2), sendo maiores que 2 nos granodioritos e menores que 1,35 nos monzogranitos e granito pegmatóide.

Elementos traços Todas as amostras analisadas revelam concentrações relativamente baixas de $\mathrm{Rb}(102$ a 163 ppm) e moderadas a elevadas de $\mathrm{Sr}(114 \mathrm{a} 430 \mathrm{ppm}$ ). O granito pegmatóide e os monzogranitos são mais ricos em $\mathrm{Rb}$ do que os granodioritos. Com exceção da amostra CL-24 A que contém $216 \mathrm{ppm}$ de $\mathrm{Zr}$, as demais apresentam concentraçôes deste elemento inferiores a $200 \mathrm{ppm}$. Os valores de $\mathrm{Y}$ e Nb são também muito baixos, porém considerados normais para esses tipos de rochas (Debon et al. 1986, Harris et al. 1986). Os valores de $\mathrm{Nb}$ aproximam-se, de um modo geral, do valor médio da crosta continental que é de $11 \mathrm{ppm}$ segundo Taylor \& McLennan (1985).

Nos monzogranitos e nos granodioritos a razão $\mathrm{Rb} / \mathrm{Sr}$ varia pouco (de 0,33 a 0,62 ), porém os valores são sempre superiores à razão média da crosta $(0,12)$. $\mathrm{O}$ granito pegmatóide apresenta uma razão $\mathrm{Rb} / \mathrm{Sr}$ mais elevada $(1,38)$ e se destaca do grupo anterior (Fig. 6A). A razão $\mathrm{K} / \mathrm{Rb}$ varia muito pouco nas rochas analisadas, sendo os seus valores próximos da média crustal (285) (Fig. 6B ).

$\mathrm{O}$ diagrama $\mathrm{Rb} / \mathrm{Sr} \times \mathrm{K} / \mathrm{Rb}$ (Fig. 7A) mostra que para valores mais ou menos constantes da razão $\mathrm{Rb} / \mathrm{Sr}$ existe um aumento da razão $\mathrm{K} / \mathrm{Rb}$ dos granodioritos para os monzogranitos. O granito pegmatóide apresenta uma razão $\mathrm{Rb} / \mathrm{Sr}$ mais elevada e foge à regra. $\mathrm{O}$ diagrama $\mathrm{K} / \mathrm{Rb} \times \mathrm{Rb}$ (Fig. $7 \mathrm{~B}$ ) indica melhor o fracionamento de $\mathrm{Rb}$. Percebe-se que há um enriquecimento maior nesse elemento no granito pegmatóide $\mathrm{e}$ nos monzogranitos do que nos granodioritos

No diagrama $\mathrm{Rb}-(\mathrm{Y}+\mathrm{Nb})$ (Fig. 8), proposto por Pearce et al. (1984) para discriminar os ambientes tectônicos de formação das rochas graníticas, os litotipos estudados encontram-se no campo dos granitos de arcos vulcânicos, porém próximo ao limite do campo dos granitos sin-colisionais.

COMPARAÇ̃̃O DOS GRANITÓIDES SANTA LUZIA COM OS GRANITÓIDES DA PORÇÃO NORTE DO CINTURÃO ARAGUAIA O primeiro trabalho mais aprofundado referente a granitóides da porção norte do Cinturão Araguaia foi realizado por Macambira (1983) que estudou um pequeno corpo granítico a duas micas intrusive em metassedimentos do Grupo Estrondo e situado a leste da estrutura braquianticlinal do Lontra, na região de Xambioá (TO) (Fig. 2). Este corpo, denominado Granito ramal do Lontra, é pobre em minerais máfícos (M 10\%), sendo constituído sobretudo por oligoclásio (An 20), quartzo e microclina. Na região de Colméia, Bulhões \& Dall'Agnol (1985) estudaram mais detalhadamente dois pequenos corpos intrusivos, localizados a leste do domo de Colméia, denominados Granodiorito Presidente Kennedy. São rochas homogêneas com foliação incipiente nas bordas cuja composição varia de granodiorítica a monzogranítica. Apresentam intensa sericitização do plagioclásio (An 8-21) e frequientes intercrescimentos mirmequíticos. Esses corpos experimentaram deformação e metamorfismo de baixo grau, porém preservaram suas características ígneas originais. A composição química das rochas 

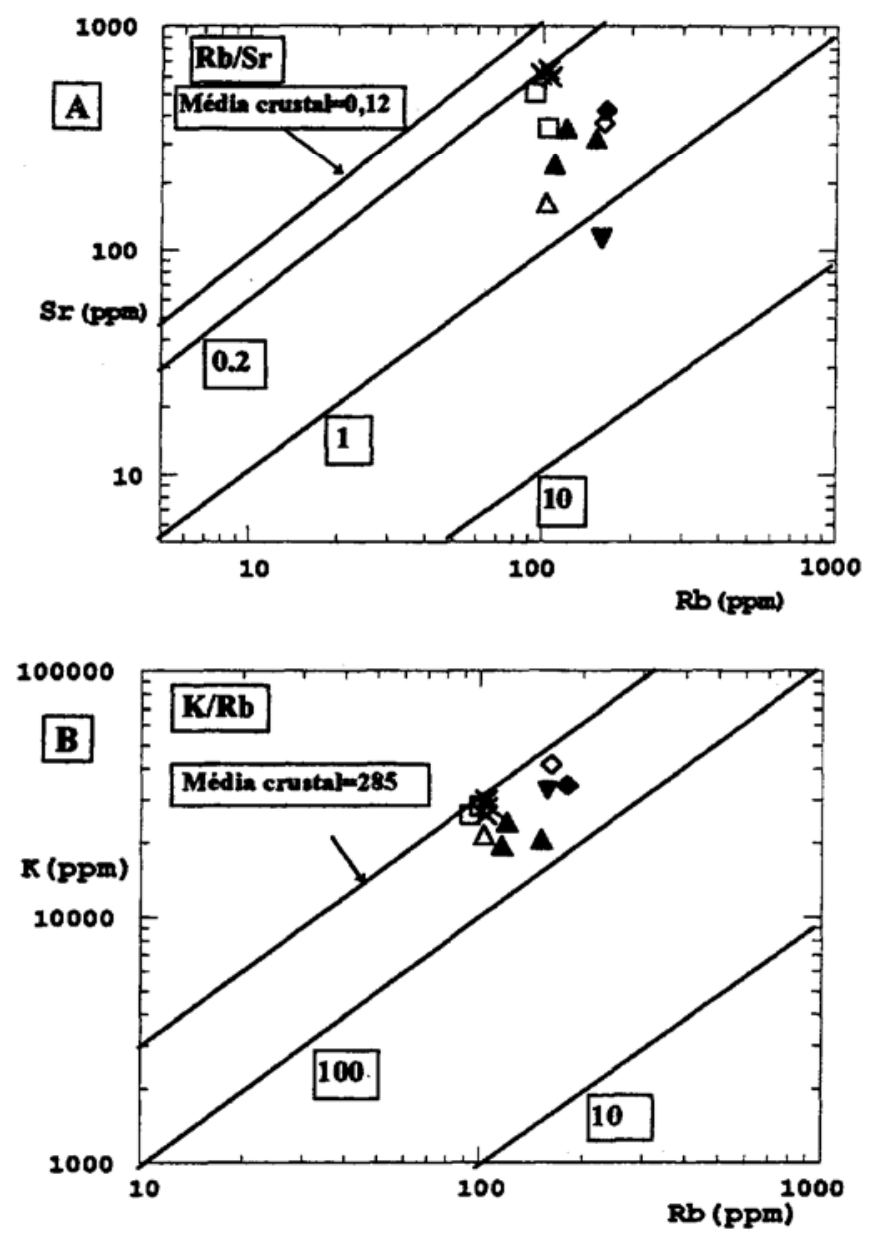

Figuras 6 - Diagramas (a) $R b \times S r(A)$ e (b) $K \times$ Rb para os granitóides Santa Luzia e aqueles da porção norte do Cinturão Araguaia (Símbolos conforme Fig.4). Figures 6 - (a) Rb x Sr and (b) K x Rb diagrams for the Santa Luzia granitoids and similar granitoids from the northern portion of the Araguaia Belt (Symbols as in Fig. 4).

granitóides que afloram no segmento norte do Cinturão Araguaia é apresentada na Tabela 3.

Essas rochas possuem teores de $\mathrm{SiO}_{2}, \mathrm{Al}_{2} \mathrm{O}_{3}, \mathrm{CaO}$ e $\mathrm{MgO}$ próximos aos dos granitóides Santa Luzia. São mais ricas em $\mathrm{Na}_{2} \mathrm{O}$ e possuem concentrações de $\mathrm{K}_{2} \mathrm{O}$ superiores às dos granodioritos, porém inferiores às dos monzogranitos e do granito pegmatóide deste estudo. Suas razões $\mathrm{Na}_{2} \mathrm{O} / \mathrm{K}_{2} \mathrm{O}$ são próximas daquelas encontradas nos granodioritos Santa Luzia (Fig. 5a). No diagrama $\mathrm{CaO}-\mathrm{Na}_{2} \mathrm{O}-\mathrm{K}_{2} \mathrm{O}$ (Fig. 5b) aproximamse do vértice $\mathrm{Na}_{2} \mathrm{O}$ como os granodioritos deste estudo.

Em termos de elementos traços, as rochas da porção norte do Cinturão Araguaia possuem teores de Rb sempre inferiores aos encontrados nos granitóides Santa Luzia, embora próximos das concentrações detectadas nos granodioritos. Por outro lado, suas concentrações de $\mathrm{Sr}$ (teor médio de $558 \mathrm{ppm}$ ) são bem superiores àquelas encontradas nos granitóides Santa Luzia (teor médio de $286 \mathrm{ppm}$ ). As razões $\mathrm{Rb} / \mathrm{Sr}$, tanto no Granodiorito Presidente Kennedy como no Granito Ramal do Lontra, são inferiores às dos granitóides Santa Luzia e aproximam-se mais da razão média da crosta continental (Fig. 6a). As razões $\mathrm{K} / \mathrm{Rb}$, por sua vez, são mais elevadas do que as obtidas neste trabalho e coincidem com a razão média crustal (Fig. 6b). A similaridade das razões $\mathrm{K} / \mathrm{Rb}$ e $\mathrm{Rb} / \mathrm{Sr}$ nas rochas da porção setentrional do Cinturão Araguaia é confirmada
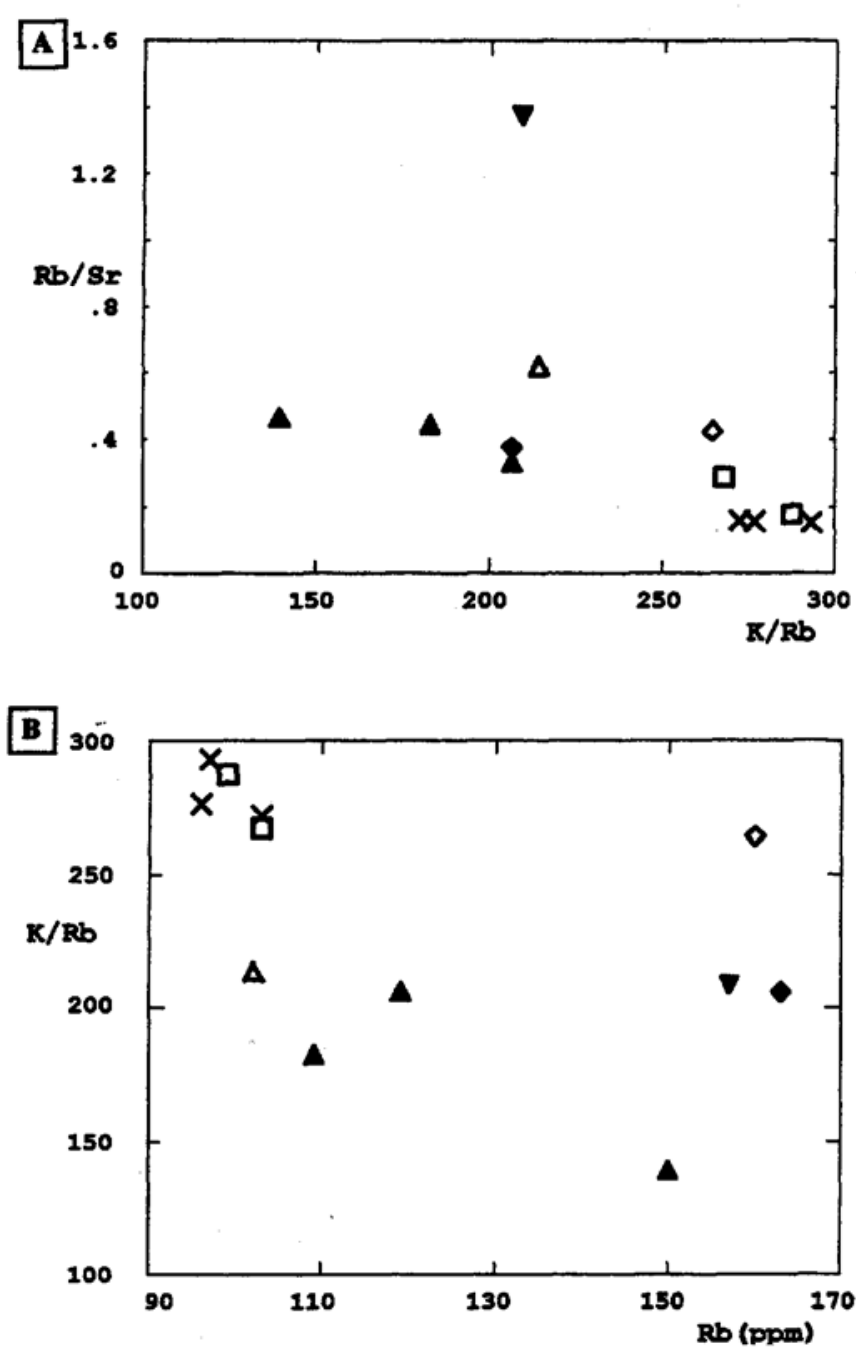

Figuras 7 - Diagramas (a) $R b / S r \times K / R b$ (b) $K / R b \times R b$ para os granitóides Santa Luzia e granitóides similares da porção norte do Cinturão Araguaia (Símbolos conforme Fig. 4). Figures 7 - (a) $\mathrm{Rb} / \mathrm{Sr} \times \mathrm{K} / \mathrm{Rb}$ and (b) K/Rb x Rb diagrams for Santa Luzia granitoids and similar granitoids from the northern segment of the Araguaia Belt (Symbols as in Fig. 4).

também pela superposição dessas amostras nos diagramas $\mathrm{Rb} / \mathrm{Sr} \times \mathrm{K} / \mathrm{Rb}$ e K/Rb x Rb (Figs. 7a e b).

DISCUSSÃO E CONCLUSÕES Com base no estudo de granitóides Santa Luzia aflorantes na região de Paraíso do Tocantins (TO), pode-se concluir que:

A) Lentes de granitóides Santa Luzia concordantes com a foliação dos xistos encaixantes são vistas em cortes da rodovia Belém-Brasflia próximo à localidade de Cachoeirinha, no Morro Dois Amigos e em outros afloramentos na vila Santa Luzia, sugerindo que o magma foi injetado concomitantemente com o metamorfísmo e a deformação que afetaram o Grupo Estrondo e deram origem ao Cinturão Araguaia. Por outro lado, nas pedreiras de Barrolândia e da Embratel (Fig. 1 ), encraves angulosos de xisto ocorrem dentro dos corpos granitóides, indicando que esse magmatismo ácido foi em parte tardio. A forma subcircular de alguns corpos e a ausência de estruturas de deformação nessas rochas corroboram esta interpretação. Além disso, granitos pegmatóides geralmente cortam os outros litotipos identificados neste trabalho. Tais 


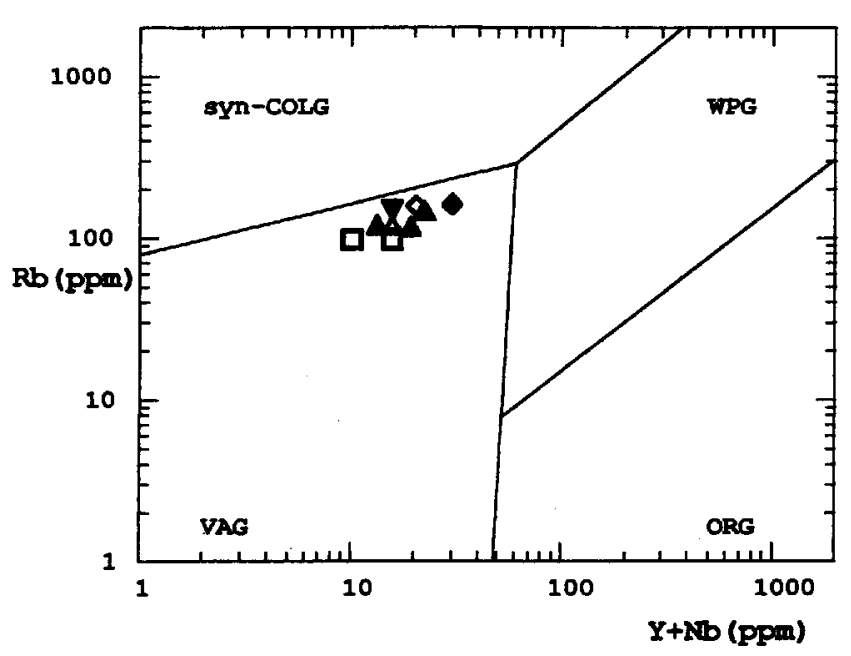

Figura 8 - Diagrama $R b-(Y+N b)$ para os granitóides Santa Luzia estudados (Simbolos conforme Fig.4).

Figure 8 - Rb- $(\mathrm{Y}+\mathrm{Nb})$ diagram for Santa Luzia granitoids (Symbols as in Fig. 4).

características sugerem, portanto, para os granitóides Santa Luzia uma natureza sin a tardi-tectônica.

B) Dentre os litotipos que constituem os granitóides Santa Luzia, predominam granodioritos e monzogranitos. Os primeiros são interpretados como a fase mais precoce, uma vez que se encontram geralmente em contato direto com os xistos encaixantes ou constituem corpos concordantes com a foliação desses últimos. Possuem granulação mais fina e contêm minerais micáceos levemente orientados. Os planos de maclamento do plagioclásio e os planos de clivagem da biotita são levemente encurvados, enquanto que os cristais de quartzo são fraturados, exibem forte extinção ondulante e mostram contatos irregulares ou denteados, provavelmente em decorrência da sua colocação ainda durante o evento tectônico.

Os monzogranitos representariam uma fase subsequente, haja vista a sua granulação mais grossa, a ausência de sinais de deformação, bem como de orientação de seus minerais micáceos.

Os granitos pegmatóides geralmente cortam os outros litotipos e são interpretados como resultantes da cristalização de magma residual rico em $\mathrm{H}_{2} \mathrm{O}$ e voláteis. Seriam, portanto, posteriores aos granodioritos e monzogranitos. A presença de turmalina, berilo e a ocorrência, no Morro Dois Amigos, de um pequeno corpo pegmatítico com textura gráfica reforça a hipótese da origem a partir de uma fase magmática hidratada rica em voláteis. Com efeito, texturas gráficas e granofíricas são interpretadas como o resultado da rápida cristalização em condições de saturação em voláteis (Fenn 1986, Lentz \& Fowler 1992).

C) Os granitóides Santa Luzia apresentam basicamente as mesmas fases minerais. São, via de regra, pobres em minerais máficos $(\mathrm{M}<10 \%)$, representados especialmente pela biotita. Os granitos pegmatóides não contêm biotita ou são muito pobres neste mineral e plotam no lado $\mathrm{Q}-(\mathrm{A}+\mathrm{P})$ do diagrama $\mathrm{Q}-(\mathrm{A}+\mathrm{P})-\mathrm{M}$. Os demais litotipos estudados apresentam um conteúdo de biotita igual ou inferior a $10 \%$. No domínio granitóide da vila Santa Luzia, percebe-se uma diminuição gradativa do conteúdo de biotita na sequeiencia granodioritomonzogranito-granito pegmatóide. Nesta mesma ordem, o plagioclásio torna-se mais sódico e há um enriquecimento em K-feldspato. Tais fatos sugerem que processos de diferenciação a partir de um magma original controlaram a evolução dessas rochas. Porém, os diagramas de Harker não mostram
Tabela 3 - Composição química do Granodiorito Presidente Kennedy e Granito Ramal do Lontra da porção norte do Cinturão Araguaia.

Table 3 - Chemical composition of the Presidente Kennedy Granodiorite and Ramal do Lontra granite from the northern portion of the Araguaia Belt.

\begin{tabular}{|c|c|c|c|c|c|}
\hline \multirow[b]{2}{*}{ óxIDOs } & \multicolumn{2}{|c|}{$\begin{array}{l}\text { Granodiorito Pres. } \\
\text { Kennedy }\end{array}$} & \multicolumn{3}{|c|}{ Granito Ramal do Lontra } \\
\hline & Corpo 1 & Corpo 2 & 289-C & 139 & 289-A \\
\hline $\mathrm{SiO}_{2}$ & 71,96 & 73,64 & 73,00 & 73,60 & 74,00 \\
\hline $\mathrm{TiO}_{2}$ & 0,25 & 0,19 & 0,15 & 0,15 & 0,16 \\
\hline $\mathrm{Al}_{2} \mathrm{O}_{3}$ & 15,30 & 15,18 & 15,16 & 15,20 & 15,40 \\
\hline $\mathrm{Fe}_{2} \mathrm{O}_{3}$ & 0,71 & 0,55 & 0,98 & 0,92 & 0,88 \\
\hline FeO & 0,92 & 0,75 & - & - & $m$ \\
\hline $\mathrm{MnO}$ & 0,03 & 0,04 & 0,02 & - & - \\
\hline MgO & 0,49 & 0,37 & 0,23 & 0,17 & 0,21 \\
\hline $\mathrm{CaO}$ & 1,64 & 1,21 & 1,31 & 1,40 & 1,26 \\
\hline $\mathrm{Na}_{2} \mathrm{O}$ & 5,18 & 5,15 & 4,85 & 4,94 & 5,31 \\
\hline $\mathrm{K}_{2} \mathrm{O}$ & 3,43 & 3,32 & $\mathbf{3 , 3 8}$ & $3, \mathbf{4 3}$ & 3,20 \\
\hline $\mathbf{P}_{2} \mathbf{O}_{3}$ & 0,10 & 0,06 & 0,05 & 0,04 & 0,04 \\
\hline $\mathbf{H}_{2} \mathbf{O}+$ & 0,54 & 0,86 & 0,37 & 0,43 & 0,50 \\
\hline TOTAL & 100,55 & 101,32 & 99,25 & 100,30 & 100,96 \\
\hline $\mathrm{Na}_{2} \mathrm{O} / \mathrm{K}_{2} \mathrm{O}$ & 1,51 & 1,55 & 1,43 & 1,44 & 1,66 \\
\hline $\mathrm{Na}_{2} \mathrm{O} / \mathrm{CaO}$ & 3,16 & 4,26 & 3,70 & 3,53 & 4,21 \\
\hline \multicolumn{6}{|l|}{ TRAÇOS } \\
\hline $\mathbf{R b}$ & 99 & 103 & 103 & 97 & 96 \\
\hline $\mathrm{Sr}$ & 554 & 357 & 647 & 622 & 610 \\
\hline $\mathbf{Z r}$ & $95 *$ & $176 *$ & 124 & 114 & 122 \\
\hline $\mathrm{Nb}$ & $<6 *$ & $9 *$ & - & - & - \\
\hline $\mathbf{B a}$ & - & - & 954 & 850 & 883 \\
\hline $\mathbf{Y}$ & $<4^{*}$ & $7 *$ & - & - & - \\
\hline $\mathbf{R b} / \mathbf{S} \mathbf{r}$ & 0,18 & 0,29 & 0,16 & 0,15 & 0,16 \\
\hline $\mathbf{K} / \mathbf{R b}$ & 288 & 267 & 272 & 294 & 277 \\
\hline
\end{tabular}

Granodiorito Presidente Kennedy = Dall'Agnol et al., 1988

Granito Ramal do Lontra = Macambira, 1983

* = Dall'Agnol (dados inéditos, comunicação escrita)

Óxidos $=\%$ em peso, elementos traços $=$ ppm

uma seqüência normal de diferenciação magmática (granodiorito - monzogranito - granito pegmatóide), o que leva a supor que as rochas enfocadas (granodioritos e monzogranitos) não são comagmáticas. Entretanto, rochas formadas pela fusão de material crustal geralmente não mostram trends clássicos de diferenciação e tendem a se agrupar no domínio dos granitos crustais (Lameyre \& Bowden 1982).

D) Os baixos conteúdos de $\mathrm{Fe}, \mathrm{Mg}$ e Ti refletem o caráter leucocrático dessas rochas. $\mathrm{O}$ teor mais elevado de $\mathrm{Mg}$ na amostra CL-18 é devido, provavelmente, à maior abundância de biotita nessa rocha $(11,3 \%)$. As concentrações de Ca são moderadas e levemente superiores à média dos granitos segundo Nockolds apud Wedepohl (1969), com exceção do granito pegmatóide que é particularmente pobre nesse elemento. 
E) O caráter peraluminoso dessas rochas, refletido na presença de biotita, muscovita, granada e turmalina (Clarke 1981), é demonstrado pelas razões À/CNK $\left(\mathrm{Al}_{2} \mathrm{O}_{3} / \mathrm{CaO}+\mathrm{Na}_{2} \mathrm{O}+\mathrm{K}_{2} \mathrm{O}\right)$ mol $>1,1$, pelos conteúdos expressivos de corindo normativo e pela ausência de diopsídio normativo (Shand 1927, Chappell \& White 1974).

F) As concentrações de $\mathrm{Rb}$ nas rochas analisadas são relativamente baixas $(170<\mathrm{ppm})$, percebendo-se que nos granodioritos este elemento é menos abundante que no granito pegmatóide e nos monzogranitos. Tal fato deve-se às maiores concentrações de $\mathrm{KaO}$ nessas últimas rochas, uma vez que os valores mais elevados de $\mathrm{Rb}$ acompanham geralmente teores mais altos de $\mathrm{K}$.

G) As razões $\mathrm{Rb} / \mathrm{Sr}$ e K/Rb mostram uma limitada variação nas rochas analisadas e aproximam-se dos valores médios definidos para a crosta continental. $\mathrm{O}$ granito pegmatóide, embora seja considerado como o litotipo mais tardio, apresenta uma razão K/Rb elevada (209), característica de rochas pouco fracionadas.

H) Com relação ao estudo comparativo entre os granitóides Santa Luzia e as rochas graníticas que afloram no segmento norte do Cinturão Araguaia, percebe-se que as composições mineralógicas dessas rochas são semelhantes e consistem basicamente em quartzo, oligoclásio e microclina com quantidades variáveis de biotita e muscovita. Apatita, zircão e, mais raramente, titanita e opacos são os minerais acessórios principais, enquanto que sericita, epidoto e clorita são os minerais de alteração mais freqüentes. São rochas leucocráticas $(\mathrm{M}<10 \%)$ cuja composição varia de granodiorítica a monzo e sienogranítica. São peraluminosas $(\mathrm{A} / \mathrm{CNK}>1,1)$ e possuem concentrações semelhantes de $\mathrm{SiO}_{2}, \mathrm{Al}_{2} \mathrm{O}_{4}, \mathrm{CaO}$ e $\mathrm{MgO}$. Os teores de $\mathrm{CaO}, \mathrm{Na}_{2} \mathrm{O}$ e $\mathrm{K}_{2} \mathrm{O}$ nas rochas da porção norte do Cinturão Araguaia estão, de um modo geral, mais próximos dos teores encontrados nos granodioritos do que nos outros tipos de granitóides Santa Luzia. Os teores de $\mathrm{Rb}$ tanto nos granitóides da porção norte do Cinturão Araguaia como nos granitóides Santa Luzia são inferiores a 170 ppm, sendo entretanto relativamente mais elevados nos monzogranitos e no granito pegmatóide da segunda associação. As concentrações de $\mathrm{Sr}$ são mais variáveis, porém mais baixas nas rochas deste estudo. As razões $\mathrm{K} / \mathrm{Rb}$ e $\mathrm{Rb} / \mathrm{Sr}$ nas rochas do segmento setentrional do cinturão variam menos e são próximas das razões médias definidas para a crosta continental, confirmando que se trata também de rochas derivadas de magmas pouco fracionados.

Diante da forte analogia entre os granitóides considerados, acredita-se que o magmatismo ácido brasiliano teve ampla distribuição no domínio do Cinturão Araguaia. Admite-se também que esses granitos foram originados a partir de rochas fontes similares. Os teores de $\mathrm{Ca}$ e $\mathrm{Sr}$ elevados, a razão inicial

${ }^{87} \mathrm{Sr} /{ }^{86} \mathrm{Sr}=0,707$ dos granitóides Santa Luzia (Lafon \& Avelar, dados inéditos) e a presença de encraves de xistos angulosos e de contatos abruptos com os granitos pegmatóides sugerem que os metassedimentos encaixantes não contribuíram, ou participaram apenas parcialmente na formação desse magma. O Complexo Colméia, como proposto inicialmente por Dall'Agnol et al.(1988), parece ser aprincipal fonte das rochas graníticas brasilianas no Cinturão Araguaia. Contudo, são necessários estudos complementares para que se chegue a uma definição mais segura da origem dessas rochas.

Agradecimentos Os autores são gratos ao Conselho Nacional de Desenvolvimento Científico e Tecnológico (CNPq), ao Projeto Faixa Orogênica do Centro de Geociências da UFPA e à PROPESP-UFPA, pelo apoio recebido.

\section{REFERÊNCIAS}

ABREU, F.A.M. 1978. Estratigrafia e evolução estrutural do segmento setentrional da Faixa de Dobramentos Paraguai-Araguaia. Belém. 90 p. (Dissertação de Mestrado, Centro de Geociências da Universidade Federal do Pará).

BARRADAS, J. A.; LAFON, J. M. \& KOTSCHOUBEY, B. 1992. Geocronologia $\mathrm{Pb}-\mathrm{Pb}$ e $\mathrm{Rb}-\mathrm{Sr}$ da região de Monte do Carmo-Porto Nacional, TO. Novos resultados. In: CONGRESSO BRASILEIRO DE GEOLOGIA, 37. São Paulo, 1992. Anais... São Paulo, SBG. v.6, p. 182-183.

BREAKS, F. W. \& MOORE Jr., J.M. 1992. The Ghost Lake Batholith, Superior Province of northwestern Ontario: A fertile, S-Type Peraluminous granite-rare element pegmatite system. Can. Mineral, 30: $835-875$.

BULHÕES, E. M. \& DALL'AGNOL, R. 1985. Mapeamento geológico e petrografia do Granodiorito Presidente Kennedy-Faixa de Dobramentos Araguaia(GO). In: SIMPÓSIO DE GEOLOGIA DA AMAZÔNIA, 2. Belém, 1985. Anais... Belém, SBG. v.1, p. 59-76.

CAPUTO, M. V. 1984. Stratigraphy, tectonics, paleoclimatology and paleogeography of northern basins of Brazil. Santa Barbara. $583 \mathrm{p}$. (Doctor of Philosofy Thesys, University of California).

CHAPPELL, B. W. \& WHITE, A. J. R. 1974. Two contrasting granite types. Pacifc Geol., 8:173-174.

CLARK, D. B. 1981. The mineralogy of peraluminous granites: A review. Can. Mineral., 19:3-17.

COSTA, J. B. S. 1980. Evolução geológica da região de Colméia-Goiás. Belém. 71 p. (Dissertação de Mestrado, Centro de Geociências da Universidade Federal do Pará).

COSTA, J. B. S.; GORAYEB, P. S. S.; BEMERGUY, R. L.; GAMA Jr., T.; KOTSCHOUBEY, B. \& LEMOS, R. L.1983. Projeto Paraíso do Norte. Relatório final. Belém, CVRD/UFPA. 125 p.

DALL'AGNOL, R.; TEIXEIRA, N. P.; MACAMBIRA， J. B.; KOTSCHOUBEY, B.; GORAYEB, P.S.S. \& SANTOS, M. D. 1988. Petrologia dos gnaisses e micaxistos da porção norte da Faixa de Dobramentos Araguaia, Goiás-Brasil. In: CONGRESSO LATINO-AMERICANO DE GEOLOGIA, 7. Belém, 1988. Anais... belém, SBG. v.1.p. 1-19.
DEBON, F.; LÊ FORT, P.; SHEPPARD, S. M. F. \& SONET, J. 1986. The Four Plutonic belts of the Transhimalaya-Himalaya: a chemical, mineralogical, isotopic, and chronological synthesis along a Tibet-Nepal section. Jour. Petrol., 27: 219-250.

FENN, P. M. 1986. On the origin of graphic granite. Am. Mineral., 71:325-330.

GORAYEB, P.S.S. 1981. Evolução geológica da região de Araguacema-Pequizeiro-Goiás. Belém. 100 p. (Dissertação de Mestrado, Centro de Geociências da Universidade Federal do Pará).

HARRIS, N. B. W.; PEARCE, J. A. \& TINDLE, A. C. 1986. Geochemical characteristics of Collision-Zone magmatism. Collision Tectonics. Geological Society Special Publication, 19:67-81.

HASUY, Y.; COSTA, J.B.S.; GORAYEB, P. S. S.; LEMOS, R. L.; GAMA Jr., T. \& BEMERGUY, R. L. 1984. Geologia do Pré-Cambriano da região de Paraíso do Norte de Goiás, (GO). In: CONGRESSO BRASILEIRO DE GEOLOGIA, 33. Rio de Janeiro, 19\&4. Anais... Rio de Janeiro, SBG. v.5, p. 22202231

HASUY, Y. \& COSTA, J.B.S. 1990.0 Cinturão Araguaia: Um novo enfoque estrutural-estratigráfico. In: CONGRESSO BRASILEIRO DE GEOLOGIA, 36. Natal, 1990. Anais... Natal, SBG. v. 6, p. 25352549.

HERZ, N.; HASUY, Y.; COSTA, J. B. S. \& MATTA, M. A. S. 1989. The Araguaia Fold Belt, Brazil: A reactivated Brasiliano-Pan-African Cycle (550 Ma) Geosuture. Precambrian Research, 42:371-386.

LAMEYRE, J. \& BOWDEN, P. 1982. Plutonic rock types series: Discrimination of various granitoid series and related rocks. Jour, of vulcanol. Geothermal Research, 14:169-186.

LENTZ, D. R. \& FOWLER, A. D. 1992. A dynamic model for granitic quartz-feldspar intergrowths in granitic pegmatites in the southwestern Greenville Province. Can. Mineral., 30:571-585.

MACAMBIRA, J. B. 1983. Geologia e ocorrências minerais da braquianticlinal do Lontra $(G O)$. Belém. 108 p. (Dissertação de Mestrado, Centro de Geociências da Universidade Federal do Pará).

MOURA, C. A. V. 1992. Geochronology and geochemistry of the basement orthogneisses of the Araguaia Belt, Brazil. Durham. 236 p. (Doctor of Philosofy Thesis, University of New Hampshire).

PEARCE, J. A.; HARRIS, N. B. \& TINDLE, A. G. 1984. Trace element discrimination diagrams for the tectonic interpretation of granitic rocks. Jour, of Petrol., 25:956-983. 
SANTOS, M. D.; MACAMBIRA, J. B. \& KOTSCHOUBEY, B. 1984. Uma proposta para a origem das braquianticlinais de Xambioá e Lontra (GO): possíveis domos gnáissicos. In: CONGRESSO BRASILEIRO DE GEOLOGIA, 33. Rio de Janeiro, 1984. Anais... Rio de Janeiro, SBG.v.7, p. 3400-3414.

SHAND, S. J. 1927. The eruptive rocks. New York, John Wiley \& Sons. 488 $\mathrm{P}-$

SOUZA, A. C. C. 1984. Geologia e Petrologia do extremo norte da Serra do Estrondo-GO. Belém. 189 p. (Dissertação de Metrado, Centro de Geociências da Universidade Federal do Pará).

SOUSA, D. 1995. Geocronologia do Granito Serrote, Tocantins. (Trabalho de Conclusão de Curso, Centro de Geociências da Universidade Federal do Pará)

STRECKEISEN, A. 1976. To each plutonic rock its proper name. Earth Science Review, 12:1 -33.

TAYLOR, S.R. \& MCLENNAN, S.M. 1985 - The continental Crust: its composition and evolution. Blackwell, Oxford, UK.
TEIXEIRA, N. P.; SOUZA, A. C. C. \& DALL'AGNOL, R. 1984. Geologia da região central da Serra das Cordilheiras, GO. In: CONGRESSO BRASILEIRO DE GEOLOGIA, 33. Rio de Janeiro, 1984. Anais... Rio de Janeiro, SBG. v.5, p. 2234-2248.

WEDEPOHL, K. H. 1969. Abundance in common magmatic rock types; terrestrial abundance. In:Wedepohl, K. H., ed. Handbook of geochemistry. Berlim, Springer-Verlag. v II/3, p. 37-E-1 a 37-E-10.

WINKLER, H.G.F. 1979. Petrogenesis of Metamorphic Rocks. 4 th ed, New York, Springer-Verlag. 334 p.

Manuscrito A911

Recebido em 10 de marco de 1997

Revisão dos autores em 28 de junho de 1997 Revisão aceita em 30 de junho de 1997 